\title{
Neofusicoccum batangarum Causing Dieback of Mango (Mangifera indica) in Florida
}

\author{
Alina S. Puig *(D) and Mike C. Winterstein \\ Subtropical Horticultural Research Station, USDA-ARS, Miami, FL 33158, USA; mike.winterstein@usda.gov \\ * Correspondence: alina.puig@usda.gov
}

check for updates

Citation: Puig, A.S.; Winterstein,

M.C. Neofusicoccum batangarum

Causing Dieback of Mango (Mangifera indica) in Florida. Agriculture 2021, 11 , 853. https://doi.org/10.3390/ agriculture11090853

Academic Editors: Grazia Licciardello and Giuliana Loconsole

Received: 6 August 2021

Accepted: 2 September 2021

Published: 7 September 2021

Publisher's Note: MDPI stays neutral with regard to jurisdictional claims in published maps and institutional affiliations.

Copyright: (c) 2021 by the authors. Licensee MDPI, Basel, Switzerland. This article is an open access article distributed under the terms and conditions of the Creative Commons Attribution (CC BY) license (https:/ / creativecommons.org/licenses/by/ $4.0 /)$.

\begin{abstract}
Mango (Mangifera indica) is an economically significant crop, and is affected by dieback in nearly all commercial production areas. Due to the wide range of organisms previously associated with these disease symptoms in Florida, isolations and pathogenicity tests were carried out to determine the causal organism. The pathogen was identified as Neofusicoccum batangarum based on genetic sequences from three loci (internal transcribed spacer of the rDNA (ITS), $\beta$-tubulin (BT), and translation elongation factor $1-\alpha(\mathrm{EF})$ ), recommended for members of the Botryosphaeriaceae family. Possible infection routes were determined by inoculating wounded and unwounded stems with $N$. batangarum. Trees wounded prior to pathogen inoculation developed larger lesions $(5.85 \mathrm{~cm} \pm 1.51)$ than unwounded trees $(0.51 \mathrm{~cm} \pm 0.48), p<0.0003$. In addition, lesions only developed at a small number of inoculation sites in the absence of wounds (14.3\%), compared to $93 \%$ when stems were wounded. No necrosis was observed in the negative controls. This study provides molecular data on N. batangarum, and evidence of its role causing mango dieback in Florida.
\end{abstract}

Keywords: Mangifera indica; Botryosphaeriaceae; vascular pathogen; Neofusicoccum batangarum; mango

\section{Introduction}

Dieback and decline affect mango (Mangifera indica) trees around the world, leading to significant yield losses in Brazil, Ghana, Oman, Pakistan, Australia, and Mexico [1-6]. The characteristic defoliation and branch necrosis can affect plants of all ages, occasionally causing death [7]. This disease has been associated with numerous fungi, however, Lasiodiplodia species are most frequently reported as the cause of mango dieback/decline $[2,7,8]$.

Mango is produced commercially in Florida, and valuable germplasm collections of this crop are maintained in the southern part of the state $[9,10]$. Dieback of mango trees has been reported in the state since the 1970 s, decreasing yield by up to $50 \%$. It has been attributed to several members of the Botryosphaeriaceae such as Neofusicoccum ribis, Diplodia sp., Dothiorella dominicana, and Lasiodiplodia theobromae, based on morphological identifications [11,12].

The Botryosphaeriaceae family contains 24 genera and 222 species [13] and has undergone numerous changes, making it difficult to interpret previous pathogen records for which there are no accompanying sequence data [14]. In addition, many species are morphologically indistinguishable, requiring sequence data from multiple loci for proper identification [15].

Four gene regions frequently used to identify members of the Botryosphaeriaceae are the internal transcribed spacer of the rDNA (ITS), $\beta$-tubulin (BT), translation elongation factor 1- $\alpha$ (EF), and RNA polymerase subunit II (RPB2) [16]. Neofusicoccum parvum can be identified with the ITS sequence, based on distinct polymorphisms it contains in this region [17], however, other members of the genus require sequences from multiple loci. BT and EF1-a are recommended for members of the N. parvum/N. ribis species complex, which contains several cryptic species [16]. The use of polymerase chain reaction (PCR) and the identification of taxonomically informative regions $[16,18]$ have made it possible to 
identify taxa causing disease on mango in Australia [5], Brazil [19], and Italy [20], within the context of newly demarcated species.

In 2018, severe branch dieback was observed on mango trees in the germplasm collection at the USDA-ARS Subtropical Horticulture Research Station in Miami, FL (Figure 1). Few shoots and leaves remained on affected trees, and black necrotic lesions were visible in the vascular tissue upon removal of bark. Disease incidence was less than $1 \%$, but the affected trees were removed to prevent further spread.

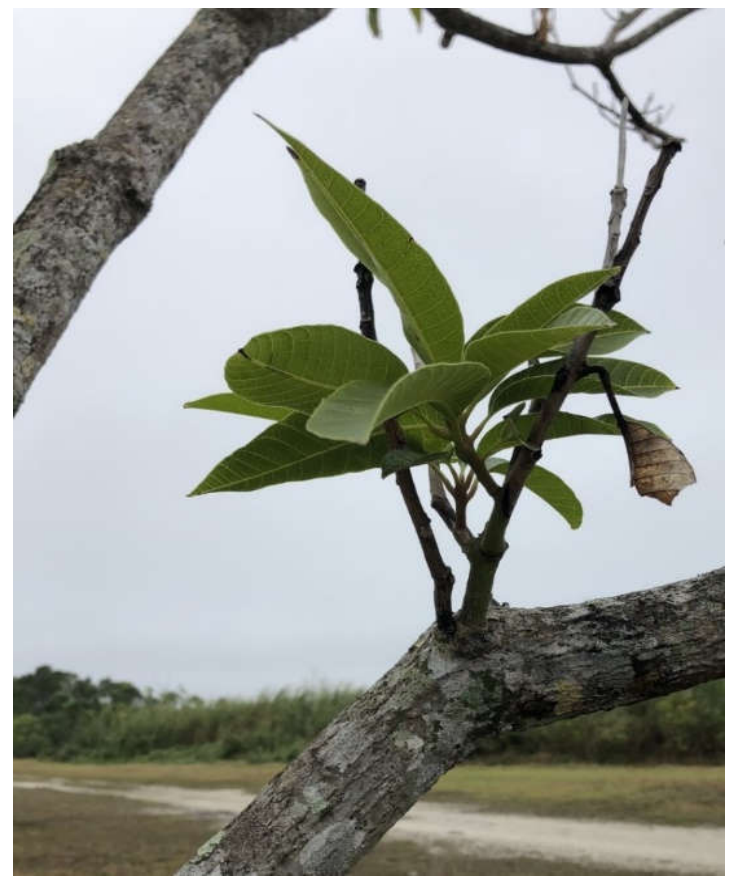

(a)

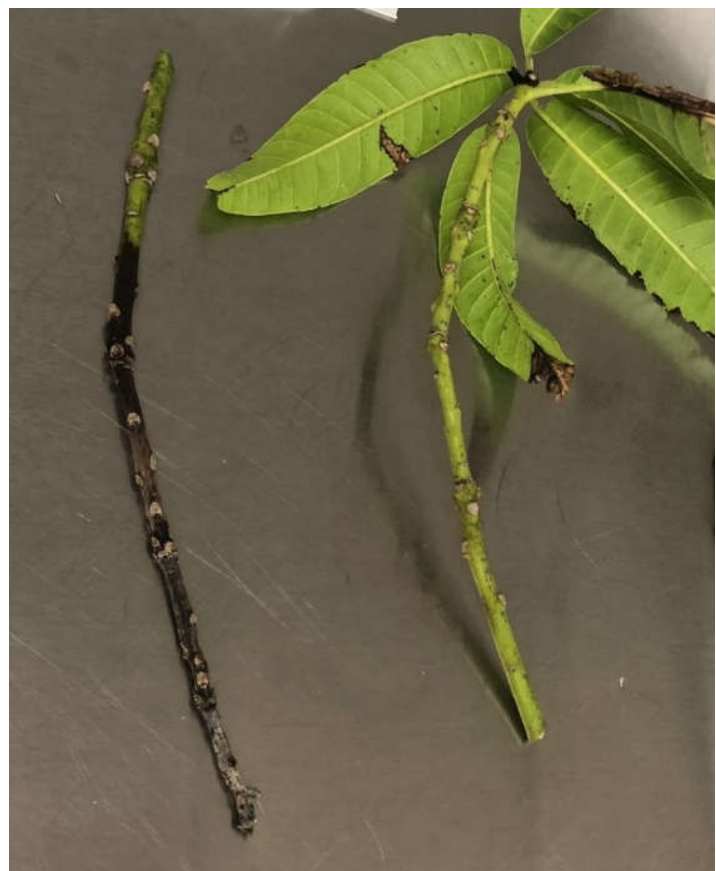

(b)

Figure 1. Mango tree with dieback caused by Neofusicoccum batangarum. (a) Few shoots and leaves remained on tree. (b) Necrotic and green shoots from affected tree.

There are no recent data on dieback of mango in Florida, and previous pathogen identifications were based solely on morphology. The purpose of this study was to use new information on the taxonomy of Botryoshphaeriaceae and molecular tools to (i) identify the species causing dieback using sequences from three separate genes, and (ii) determine the role of wounding in the infection cycle by comparing disease development on wounded and intact stems.

\section{Materials and Methods}

\subsection{Pathogen Isolation and DNA Extraction}

Symptomatic material was collected from two trees at the USDA-ARS mango collection (MIA 36084, MIA 35514) and one tree in a nearby residential area, showing similar symptoms. Xylem tissue was processed by excising pieces (approximately $3 \times 15 \times 3 \mathrm{~mm}^{3}$ ) from lesion margins comprising both healthy and necrotic tissue, surface-disinfesting by immersing in $70 \%$ ethanol for $20 \mathrm{~s}$, then air drying on autoclaved filter paper. These pieces were cut into $1 \times 5 \times 3 \mathrm{~mm}^{3}$ pieces and plated on $1 / 2$ strength potato dextrose agar (PDA) (Sigma Chemical Co., St. Louis, MO, USA; $19.5 \mathrm{~g}$ PDA, $7.5 \mathrm{~g}$ agar, and $1 \mathrm{~L}$ distilled water), and incubated at $25\left( \pm 3^{\circ} \mathrm{C}\right)$ in the dark.

Emerging hyphae from one to two isolates from each tree were subcultured on new plates of $1 / 2$ PDA. After five days, mycelium was harvested from the five isolates by gently scraping with a sterile scalpel, transferred to $1.5 \mu \mathrm{L}$ microcentrifuge tubes with a single stainless steel bead, and mechanically macerated using a TisueLyser machine (Qiagen, 
Valencia, CA, USA). DNA was extracted using the Qiagen DNeasy Plant Mini Kit, following the manufacturer's protocol (Qiagen, Valencia, CA, USA).

\subsection{Pathogen Identification}

To identify the isolated organism, the complete internal transcriber spacer rDNA (ITS), partial $\beta$-tubulin (BT), and translation elongation factor $1-\alpha$ (TEF1) gene regions were amplified and sequenced using primers ITS5 (5' GGAAGTAAAAGTCGTAACAAGG 3') and ITS4 ( $5^{\prime}$ TCCT CCGCTTATTGATATGC $\left.3^{\prime}\right)$ [21], BT2A (5' GGTAACCAAATCGGTG CTGCTTTC $\left.3^{\prime}\right)$ and BT2B (5' ACCCTCAGTGTAGTGACCCTTGGC $\left.3^{\prime}\right)$ [22], and EF1-728F (5' CATCGAGAAGTTCGAGAAGG $\left.3^{\prime}\right)$ and EF1-986R (5' TACTTGAAGGAACCCTTACC $\left.3^{\prime}\right)$ [23], respectively.

One microliter of DNA was used as template in a $25 \mu \mathrm{L}$ PCR reaction consisting of $12.5 \mu \mathrm{L} 2 \mathrm{x}$ Immomix Red (Bioline, Taunton, MA, USA), $1 \mu \mathrm{L}$ each of $10 \mu \mathrm{m}$ forward and reverse primer, and sterile nuclease free water to $25 \mu \mathrm{L}$. For ITS, amplification was achieved using the following thermocycler conditions: $94{ }^{\circ} \mathrm{C}$ for $10 \mathrm{~min}$; then, 30 cycles of $95^{\circ} \mathrm{C}$ for $30 \mathrm{~s}, 57^{\circ} \mathrm{C}$ for $30 \mathrm{~s}$, and $72{ }^{\circ} \mathrm{C}$ for $45 \mathrm{~s}$; followed by a final primer extension step of $72{ }^{\circ} \mathrm{C}$ for $5 \mathrm{~min}$.

$\mathrm{BT}$ and $\mathrm{EF}$ were amplified using the following touchdown program: $95^{\circ} \mathrm{C}$ for $12 \mathrm{~min}$; then, 34 cycles of $94{ }^{\circ} \mathrm{C}$ for $1 \mathrm{~min}, 56^{\circ} \mathrm{C}$ for $45 \mathrm{~s}$ (decreasing by $0.3^{\circ} \mathrm{C} /$ cycle), and $72{ }^{\circ} \mathrm{C}$ for $1 \mathrm{~min}$; followed by a final primer extension step of $72{ }^{\circ} \mathrm{C}$ for $5 \mathrm{~min}$. All PCRs were performed on a Bio-Rad C1000 Touch thermal cycler (Bio- Rad Laboratories, Inc., Hercules, CA, USA).

Amplified products were electrophoresed on $1 \%(w / v)$ agarose gels containing $8 \mu \mathrm{L}$ of Biotium GelRed (Biotium, Fremont, CA, USA) and visualized using a Syngene InGenius Gel Imaging System (Syngene USA Inc, Frederick, MD, USA) and GeneSnap software version 7.08. PCR products were purified using the Qiagen PCR Purification Kit (Qiagen, Hilden, Germany), then bi-directionally Sanger sequenced by Eurofins Genomics (Louisville, KY, USA). Forward and reverse sequences were aligned and edited using Geneious 11.1.2 (Biomatters Ltd., Auckland, New Zealand) and analyzed in BLASTn (NCBI, http:/ / www. ncbi.nlm.nih.gov (accessed on 27 July 2021)) for identification.

\subsection{Temperature Growth Response}

The influence of temperature on growth of five $N$. batangarum isolates obtained in this study was determined in a range of temperatures $\left(5^{\circ} \mathrm{C}\right.$ to $40{ }^{\circ} \mathrm{C}$ in $5^{\circ}$ intervals). Agar plugs $(6 \mathrm{~mm})$ were taken from 2-day-old cultures growing at $25 \pm 2{ }^{\circ} \mathrm{C}$ on $2 \%$ malt extract agar (MEA) Petri dishes $\left(85 \times 15 \mathrm{~mm}^{2}\right)$ and placed top side down in the center of new $2 \%$ MEA plates, with three to four replicates per isolate. The plates were wrapped with Parafilm and placed in the dark at the selected temperature. After 3 days, the radii ( $\mathrm{mm})$ were measured twice for each plate at right angles to each other. The radius of the original agar plug $(3 \mathrm{~mm})$ was subtracted to obtain radial growth values, then averaged to produce a single measurement per plate.

\subsection{Inoculation Study}

To compare the ability of $N$. batangarum to infect wounded and unwounded stems, and to fulfill Koch's postulates, an inoculation study was carried out on two-year-old Mangifera indica cv. 'Turpentine' seedlings. These plants were grown in a shadehouse in a customized 'nursery mix' (50\% pinebark, $10 \%$ sand, $40 \%$ coir pyth, $9 \#$ Dolomite/yd, $3 \#$ MicroMax/yd), and ranged from $50-120 \mathrm{~cm}$ in height and 1-1.5 cm in diameter. Wounded stem inoculations were carried out on 5 plants by cutting $1 \times 1 \mathrm{~cm}^{2}$ flaps in the bark (approximately $0.3 \mathrm{~cm}$ depth), inserting mycelial discs $\left(0.6 \mathrm{~cm}^{2}\right)$ from 3-day-old cultures of N. batangarum, and sealing the site with Parafilm (Figure 2). 


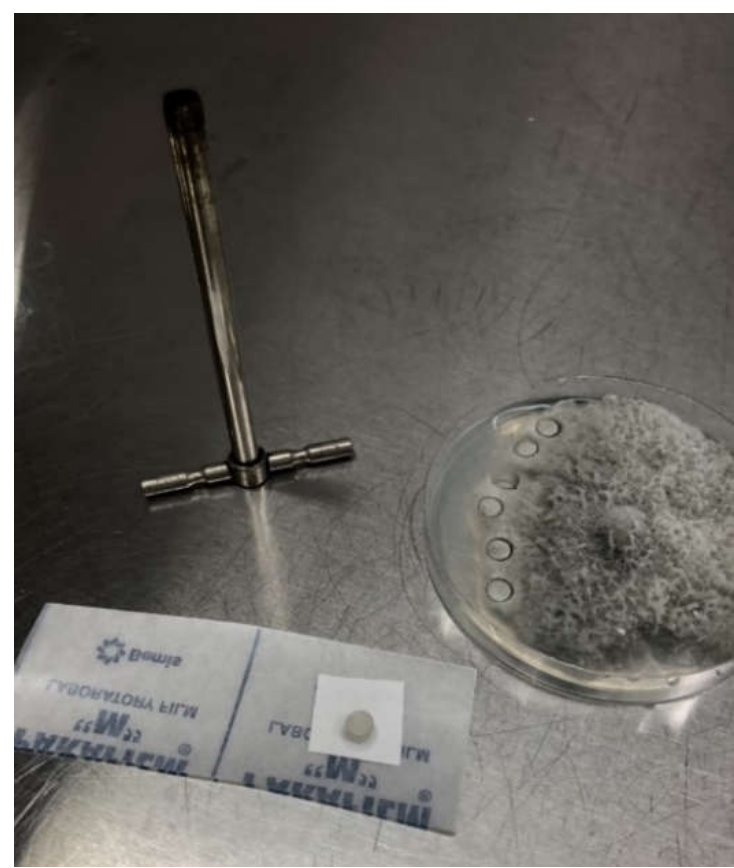

(a)

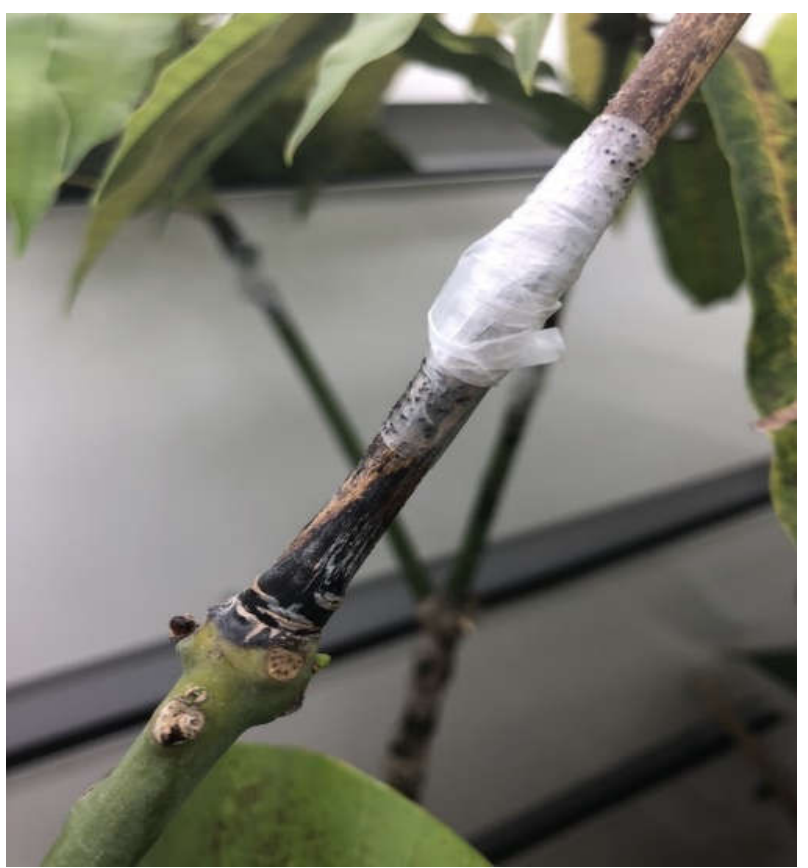

(b)

Figure 2. Koch's postulates on Mangifera indica. (a) wounded stems were inoculated with mycelial plugs from 3-day-old cultures of Neofusicoccum batangarum and wrapped in Parafilm to prevent desiccation. (b) Lesions were measured five weeks post-inoculation.

Unwounded stem inoculations were carried out on seven trees, as described previously, but without perforating, or otherwise modifying, the bark in advance. Three additional trees were wound-inoculated with discs of sterile 1/2 PDA to serve as negative controls. All trees were inoculated at three different points along the stem. Plants were kept in Percival Growth Chambers within the USDA-ARS Plant Pathology laboratory $\left(25^{\circ} \mathrm{C}\right.$; $12 \mathrm{~h}$ light/dark), and watered three times a week.

Five weeks post-inoculation, the bark was removed, and vertical lesion length in the xylem was recorded after subtracting the length of the inoculation flap (on wounded plants). Lesion length at each inoculation site was averaged to obtain one value per tree. To determine whether lesion size differed based on the presence of a wound prior to inoculation, an independent $t$-test was carried out on vertical lesion length, using SAS Ver. 9.4 (SAS Institute Inc, Cary, NC, USA). To confirm the symptoms were caused by the inoculated organism, and fulfill Koch's postulates, all lesions were processed as described above and the identity of the re-isolated organism was confirmed based on morphology.

\section{Results}

\subsection{Pathogen Identification}

A fast-growing fungus with white, aerial mycelia that began turning dark gray after 4 days was isolated from all samples. BLASTn analysis identified the organism as Neofusicoccum batangarum based on the ITS $(100 \%$ match to numerous $N$. batangarum entries, such as MT587475 from Spondias dulcis from the USA), BT (100\% match to MN952208 from Anacardium occidentale in Guinea-Bissau), and TEF1 (100\% match to MK294149 from Nephelium lappaceum in Puerto Rico). For the ITS sequences, all GenBank entries sharing $100 \%$ identity and $100 \%$ coverage belonged to $N$. batangarum accessions. Three sequences of a single isolate (Mg4) were deposited in GenBank as accession nos. MZ244205, MZ520981, and MZ355919 for ITS, BT, and TEF1, respectively. 


\subsection{Temperature Growth Effect}

Temperature responses of five N. batangarum isolates (named Mg1-Mg5) were assessed to determine growth rate and ideal conditions. Maximum growth of all isolates was recorded at $30{ }^{\circ} \mathrm{C}$, with mean radii ranging from $21.3 \mathrm{~mm}( \pm 1.7 \mathrm{~mm})$ to $33.1 \mathrm{~mm}( \pm 0.6 \mathrm{~mm})$ (Figure 3). No growth was observed at $5{ }^{\circ} \mathrm{C}$ or $40{ }^{\circ} \mathrm{C}$, indicating these are below and above the cardinal temperatures of $\mathrm{N}$. batangarum. $\mathrm{Mg} 3$ had the lowest growth at all temperatures tested.

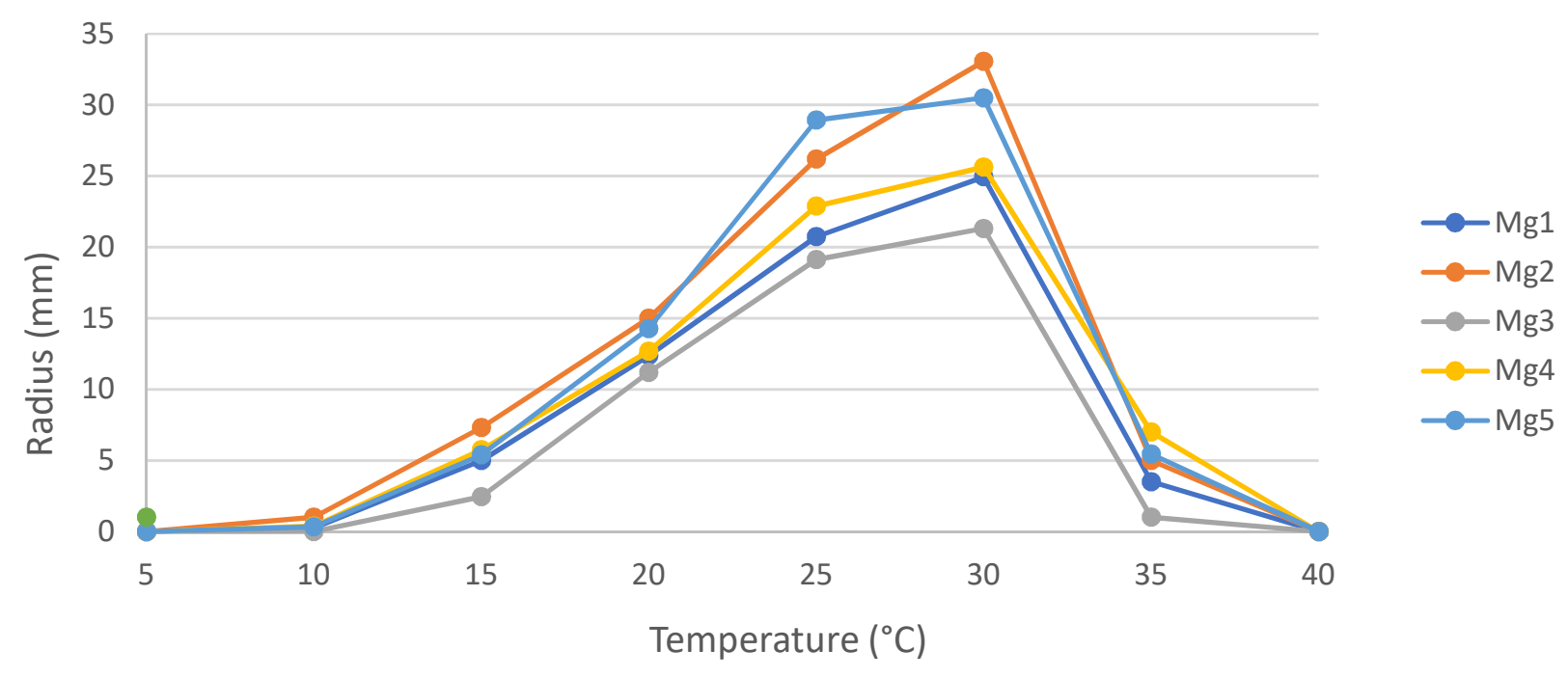

Figure 3. Mean radial growth of Neofusicoccum batangarum isolates $(n=5)$ from Mangifera indica after three days on $2 \%$ malt extract agar. Growth was measured at $5^{\circ} \mathrm{C}, 10^{\circ} \mathrm{C}, 15^{\circ} \mathrm{C}, 20^{\circ} \mathrm{C}, 25^{\circ} \mathrm{C}, 30^{\circ} \mathrm{C}, 35^{\circ} \mathrm{C}$, and $40^{\circ} \mathrm{C}$. No growth was observed at $5^{\circ} \mathrm{C}$ or $40^{\circ} \mathrm{C}$.

\subsection{Inoculation Study}

Wounded trees inoculated with the $N$. batangarum developed black necrotic lesions at 14 of the 15 inoculation points $(93.3 \%)$. Removal of the bark showed necrosis in the xylem that was identical to the symptoms originally seen in the field-collected samples (Figure 4a,b). N. batangarum was re-isolated from all of these, thus fulfilling Koch's postulates and confirming pathogen identity. No necrosis was observed in the negative controls.

Possible infection routes were determined by comparing disease development in wounded and unwounded stems inoculated with the pathogen. Trees wounded prior to pathogen inoculation developed larger lesions $(5.85 \mathrm{~cm} \pm 1.51)$ than unwounded trees $(0.51 \mathrm{~cm} \pm 0.48), t(10)=-3.53, p<0.0003$. In addition, lesions only developed at a small number of inoculation sites in the absence of wounds (14.3\%). Xylem tissue from all inoculation sites was surface-disinfested and plated on $1 / 2$ PDA to determine whether $N$. batangarum had colonized the tissue, but the pathogen was only recovered from symptomatic tissue. 


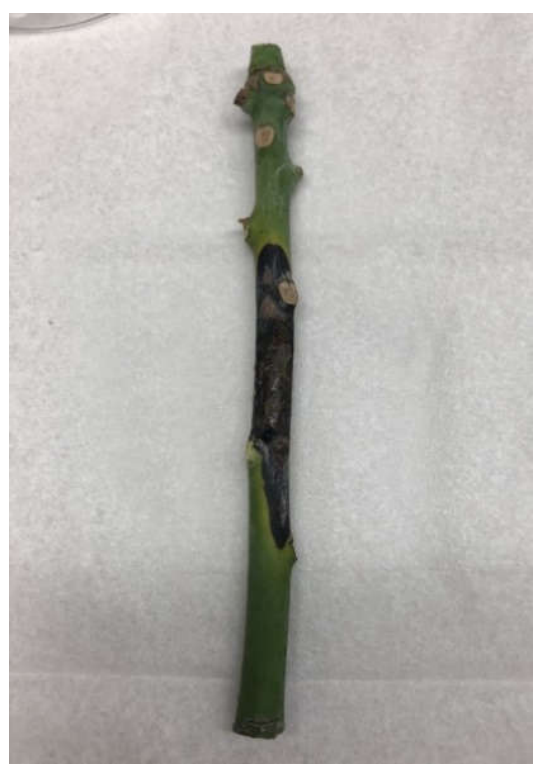

(a)

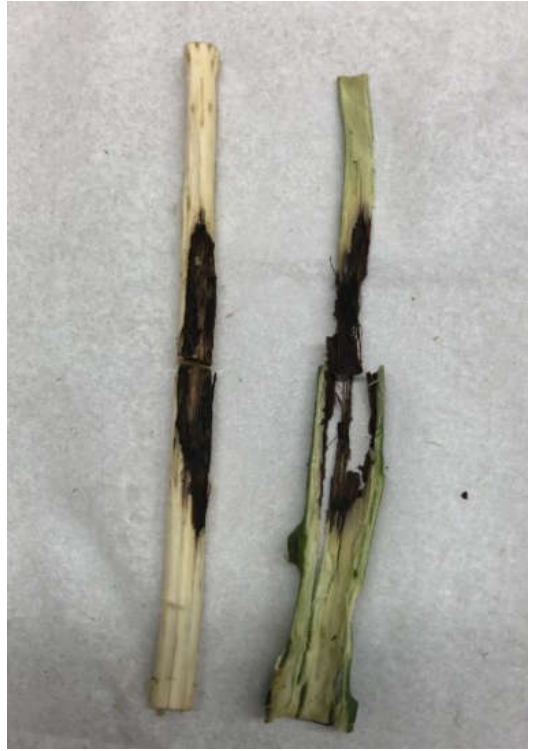

(b)

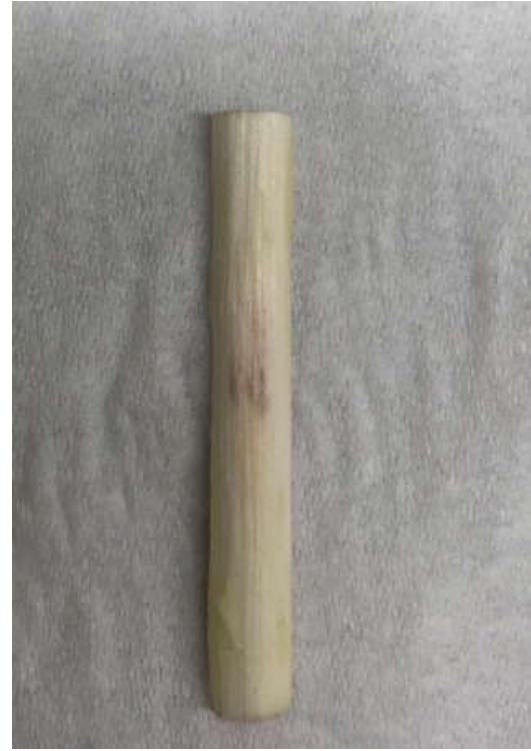

(c)

Figure 4. Symptoms on Mangifera indica seedlings inoculated with Neofusicoccum batangarum after wounding. (a) Lesions were measured 35 days after inoculation, by which time necrosis had developed on stem exterior. (b) Nearly black necrotic lesions developed in xylem of inoculated stems, identical to original disease symptoms. (c) Negative control trees (inoculated with plugs of $1 / 2$ PDA) developed mild discoloration at the inoculation point but no necrosis was observed.

\section{Discussion}

This study identifies N. batangarum as a causal agent of mango dieback in Florida, USA, based on molecular data, and provides valuable preliminary information on infection routes that can be used to improve disease management. Species identification was carried out using genetic sequences from three separate genes to account for the taxonomic complexity of fungi in the Botryosphaeriaceae. Although sequences of N. batangarum isolated from M. indica are present in GenBank (MT592187, MT587474, MT592679), no information was provided regarding the presence of symptoms [24].

The closely related Neofusicoccum ribis was associated with mango dieback in Florida 30 years ago, based on morphological identification [25]. However, detailed phylogenetic studies have shown that $N$. ribis is part of a species complex containing cryptic species that can only be identified using sequences from multiple loci [17], and many of the species in this complex were only recently described. For example, Neofusicoccum batangarum was described as a species in 2010, after being isolated from Terminalia catappa in Cameroon [18]. Since then, it has been reported causing disease on grapevine in Brazil [26], cashew in Brazil and Guinea-Bissau [27,28], rambutan and longan in Puerto Rico [29], and prickly pear in Sicily [30]. This fungus has a wide potential host range that includes many commercially valuable crops.

In 2011, N. batangarum was reported in Florida, where it had been isolated from seeds of the invasive Brazilian peppertree (Schinus terebinthifolius) [31], on which it was found to be a virulent pathogen and potential biocontrol agent. Oddly, artificial inoculations of mango plants with $N$. batangarum during that study did not induce dieback symptoms [31]. Both plants are in the Anacardiaceae family. It is expected that N. batangarum is merely one of several organisms responsible for mango dieback in Florida.

Branch dieback affects mango around the world, and genetic tools are now being used to determine the causal pathogens, while accounting for newly described and cryptic species. In Spain, ITS, BT, and EF sequences identified N. parvum as causing a lethal dieback disease on mango trees grown under greenhouse conditions [32]. Both N. parvum and $N$. australe have been reported causing branch dieback on mango in Italy, leading to the 
death of whole trees [20]. These loci can also be used to identify related Lasiodiplodia spp., which are most frequently associated with dieback on mango [2-4]

Based on results from this study, optimum growth of $N$. batangarum isolates affecting mango in Miami, Florida occurs around $30^{\circ} \mathrm{C}$, with no growth $\leq 5^{\circ} \mathrm{C}$ or $\geq 40^{\circ} \mathrm{C}$. This range corresponds with temperatures recorded in the area. With an average low temperature in Miami of $15.5^{\circ} \mathrm{C}$ [33], it can be assumed that the disease cycle does not include an overwintering stage, in contrast to related genera such as N. paroum [34].

Epidemiological studies in vineyards identified airborne spores as the primary source of inoculum for Botryosphaeriaceae species, with conidia becoming airborne shortly after rainfall [35] or being dispersed in rainwater [36]. In grapevines infected with Neofusicoccum and Diplodia spp., conidia were produced on necrotic tissue of young shoots as well as woody branches [37]. This suggests that removal of symptomatic tissue could decrease the amount of inoculum present and prevent additional infections. Inoculation studies with $N$. luteum, N. parvum, and N. australe showed that these fungi were unable to infect wounded roots [38].

\section{Conclusions}

This study provides molecular data on $N$. batangarum, and evidence of its role in causing mango dieback in Florida. The sequence data provided will make it possible to update pathogen nomenclature as members of the Botryosphaeriaceae continue to be reorganized and renamed. They will also be valuable for future researchers to detect shifts in pathogen populations over time. Commercial mango production encompasses approximately 1350 acres in Florida [8], and information on this pathogen is relevant to growers in the area.

Supplementary Materials: The following are available online at https:/ /www.mdpi.com/article/10 .3390 /agriculture11090853/s1, Supplementary File: N. batangarum growth at various temperatures.

Author Contributions: Conceptualization, A.S.P. and M.C.W.; methodology, A.S.P. and M.C.W.; software, A.S.P.; validation, A.S.P.; formal analysis, A.S.P.; investigation, A.S.P. and M.C.W.; resources, A.S.P.; data curation, A.S.P.; writing—original draft preparation, A.S.P. and M.C.W.; writing-review and editing, A.S.P. and M.C.W.; visualization, A.S.P.; supervision, A.S.P.; project administration, A.S.P.; funding acquisition, A.S.P. All authors have read and agreed to the published version of the manuscript.

Funding: This research received no external funding.

Institutional Review Board Statement: Not applicable.

Informed Consent Statement: Not applicable.

Data Availability Statement: Radial growth data are available in the Supplementary File and genetic sequences are available in GenBank.

Acknowledgments: We thank Wil Quintanilla (USDA-ARS, Miami FL) for his technical assistance, and Mat Dane (Miami FL) for providing samples. We also thank Jerome Niogret (Niogret Ecology Consulting LLC, 2980 Sw 25th St, Miami, FL, USA) and Barbara Freeman (USDA-ARS, Miami, FL, USA), for critical reviews of this manuscript.

Conflicts of Interest: The authors declare no conflict of interest.

\section{References}

1. De Oliveira Costa, V.S.; Michereff, S.J.; Martins, R.B.; Gava, C.A.T.; Mizubuti, E.S.G.; Câmara, M.P.S. Species of Botryosphaeriaceae associated on mango in Brazil. Eur. J. Plant. Pathol. 2010, 127, 509-519. [CrossRef]

2. Ablormeti, F.; Coleman, S.; Honger, J.; Owusu, E.; Bedu, I.; Aidoo, O.; Cornelius, E.; Odamtten, G. Management of Lasiodiplodia theobromae, the causal agent of mango tree decline disease in Ghana. Afr. Crop. Sci. J. 2021, 29, 193-207. [CrossRef]

3. Al Adawi, A.; Deadman, M.; Al Rawahi, A.; Al Maqbali, Y.; Al Jahwari, A.; Al Saadi, B.; Al Amri, I.; Wingfield, M. Aetiology and causal agents of mango sudden decline disease in the Sultanate of Oman. Eur. J. Plant. Pathol. 2006, 116, 247-254. [CrossRef]

4. Khanzada, M.A.; Lodhi, A.M.; Shahzad, S. Chemical control of Lasiodiplodia theobromae, the causal agent of mango decline in Sindh. Pak. J. Bot. 2005, 37, 1023. 
5. Sakalidis, M.L.; Ray, J.D.; Lanoiselet, V.; Hardy, G.E.S.; Burgess, T.I. Pathogenic Botryosphaeriaceae associated with Mangifera indica in the Kimberley region of Western Australia. Eur. J. Plant. Pathol. 2011, 130, 379-391. [CrossRef]

6. Sandoval-Sánchez, M.; Nieto-Ángel, D.; Sandoval-Islas, J.S.; Téliz-Ortiz, D.; Orozco-Santos, M.; Silva-Rojas, H. Fungi associated to stem-end rot and dieback of mango (Mangifera indica L.). Agrociencia 2013, 47, 61-73.

7. Rodríguez-Gálvez, E.; Guerrero, P.; Barradas, C.; Crous, P.W.; Alves, A. Phylogeny and pathogenicity of Lasiodiplodia species associated with dieback of mango in Peru. Fungal Biol. 2017, 121, 452-465. [CrossRef] [PubMed]

8. Saeed, E.E.; Sham, A.; AbuZarqa, A.; A Al Shurafa, K.; S Al Naqbi, T.; Iratni, R.; El-Tarabily, K.; F AbuQamar, S. Detection and management of mango dieback disease in the United Arab Emirates. Int. J. Mol. Sci. 2017, 18, 2086. [CrossRef]

9. Crane, J. Tropical fruit production in Florida: Trials, tribulations and opportunities. Proc. Fla. State Hort. Soc 2018.

10. Ledesma, N. Economic feasibility of small-scale specialty mango production in South Florida. In Proceedings of the Florida State Horticultural Society, Saint Augustine, FL, USA, 31 May-2 June 2015; pp. 25-27.

11. Ramos, L.J.; Davenport, T.L.; McMillan Jr, R.T.; Lara, S.P. The resistance of mango (Mangifera indica) cultivars to tip dieback disease in Florida. Plant. Dis. 1997, 81, 509-514. [CrossRef]

12. Ploetz, R.C.; Benscher, D.; Vazquez, A.; Colls, A.; Nagel, J.; Schaffer, B. A reexamination of mango decline in Florida. Plant. Dis. 1996, 80, 664-668. [CrossRef]

13. Burgess, T.I.; Tan, Y.P.; Garnas, J.; Edwards, J.; Scarlett, K.A.; Shuttleworth, L.A.; Daniel, R.; Dann, E.K.; Parkinson, L.E.; Dinh, Q. Current status of the Botryosphaeriaceae in Australia. Australas. Plant. Pathol. 2019, 48, 35-44. [CrossRef]

14. Slippers, B.; Johnson, G.I.; Crous, P.W.; Coutinho, T.A.; Wingfield, B.D.; Wingfield, M.J. Phylogenetic and morphological re-evaluation of the Botryosphaeria species causing diseases of Mangifera indica. Mycologia 2005, 97, 99-110. [CrossRef]

15. Phillips, A.; Alves, A.; Abdollahzadeh, J.; Slippers, B.; Wingfield, M.J.; Groenewald, J.; Crous, P.W. The Botryosphaeriaceae: Genera and species known from culture. Stud. Mycol. 2013, 76, 51-167. [CrossRef]

16. Sakalidis, M.L.; Hardy, G.E.S.J.; Burgess, T.I. Use of the Genealogical Sorting Index (GSI) to delineate species boundaries in the Neofusicoccum parvum-Neofusicoccum ribis species complex. Mol. Phylogenetics Evol. 2011, 60, 333-344. [CrossRef]

17. Sakalidis, M.; Slippers, B.; Wingfield, B.D.; Hardy, G.S.J.; Burgess, T. The challenge of understanding the origin, pathways and extent of fungal invasions: Global populations of the Neofusicoccum parvum-N. ribis species complex. Divers. Distrib. 2013, 19, 873-883. [CrossRef]

18. Begoude, B.D.; Slippers, B.; Wingfield, M.J.; Roux, J. Botryosphaeriaceae associated with Terminalia catappa in Cameroon, South Africa and Madagascar. Mycol. Prog. 2010, 9, 101-123. [CrossRef]

19. Marques, M.W.; Lima, N.B.; de Morais, M.A.; Michereff, S.J.; Phillips, A.J.; Câmara, M.P. Botryosphaeria, Neofusicoccum, Neoscytalidium and Pseudofusicoccum species associated with mango in Brazil. Fungal Divers. 2013, 61, 195-208. [CrossRef]

20. Ismail, A.; Cirvilleri, G.; Lombard, L.; Crous, P.; Groenewald, J.; Polizzi, G. Characterisation of Neofusicoccum species causing mango dieback in Italy. J. Plant. Pathol. 2013, 95, 549-557.

21. White, T.J.; Bruns, T.; Lee, S.; Taylor, J. Amplification and direct sequencing of fungal ribosomal RNA genes for phylogenetics PCR Protoc. A Guide Methods Appl. 1990, 18, 315-322.

22. Glass, N.L.; Donaldson, G.C. Development of primer sets designed for use with the PCR to amplify conserved genes from filamentous ascomycetes. Appl. Environ. Microbiol. 1995, 61, 1323-1330. [CrossRef]

23. Carbone, I.; Kohn, L.M. A method for designing primer sets for speciation studies in filamentous ascomycetes. Mycologia 1999, 91, 553-556. [CrossRef]

24. Zhang, W.; Groenewald, J.; Lombard, L.; Schumacher, R.; Phillips, A.; Crous, P. Evaluating species in Botryosphaeriales. Pers.-Mol. Phylogeny Evol. Fungi 2020, 46, 63-115.

25. Ramos, L.; Lara, S.; McMillan Jr, R.; Narayanan, K. Tip dieback of mango (Mangifera indica) caused by Botryosphaeria ribis. Plant. Dis. 1991, 75, 315-318. [CrossRef]

26. Rêgo, T.J.; Silva, F.J.; Santos, K.M.; Câmara, M.P.; Correia, K.C.; Michereff, S.J. First report of Neofusicoccum batangarum causing grapevine dieback in Brazil. J. Plant. Pathol. 2020, 102, 973. [CrossRef]

27. Netto, M.S.; Lima, W.G.; Correia, K.C.; Da Silva, C.F.; Thon, M.; Martins, R.B.; Miller, R.N.; Michereff, S.J.; Câmara, M.P. Analysis of phylogeny, distribution, and pathogenicity of Botryosphaeriaceae species associated with gummosis of Anacardium in Brazil, with a new species of Lasiodiplodia. Fungal Biol. 2017, 121, 437-451. [CrossRef] [PubMed]

28. Diniz, I.; Batista, D.; Pena, A.R.; Rodrigues, A.S.B.; Reis, P.; Baldé, A.; Indjai, B.; Catarino, L.; Monteiro, F. First Report of Dieback Caused by Neofusicoccum batangarum in Cashew in Guinea-Bissau. Plant. Dis. 2021, 105, 1215. [CrossRef] [PubMed]

29. Serrato-Diaz, L.; Aviles-Noriega, A.; Soto-Bauzó, A.; Rivera-Vargas, L.; Goenaga, R.; Bayman, P. Botryosphaeriaceae fungi as causal agents of dieback and corky bark in rambutan and longan. Plant. Dis. 2020, 104, 105-115. [CrossRef] [PubMed]

30. Francesco, A.; Giambra, S.; Schena, L.; Surico, G.; Antonella, P.; Gusella, G.; Stracquadanio, C.; Burruano, S.; Cacciola, S.O. New insights into scabby canker of Opuntia ficus-indica, caused by Neofusicoccum batangarum. Phytopathol. Mediterr. 2020, 59, 269-284.

31. Shetty, K.G.; Minnis, A.M.; Rossman, A.Y.; Jayachandran, K. The Brazilian peppertree seed-borne pathogen, Neofusicoccum batangarum, a potential biocontrol agent. Biol. Control. 2011, 56, 91-97. [CrossRef]

32. Arjona-Girona, I.; López-Herrera, C. First report of branch dieback in mango trees caused by Neofusicoccum parvum in Spain. Plant. Dis. 2016, 100, 2529. [CrossRef]

33. U.S. Climate Data. Available online: https:/ / www.usclimatedata.com (accessed on 5 August 2021). 
34. Zhou, Y.; Gong, G.; Cui, Y.; Zhang, D.; Chang, X.; Hu, R.; Liu, N.; Sun, X. Identification of Botryosphaeriaceae species causing kiwifruit rot in Sichuan Province, China. Plant. Dis. 2015, 99, 699-708. [CrossRef] [PubMed]

35. Úrbez-Torres, J.; Battany, M.; Bettiga, L.; Gispert, C.; McGourty, G.; Roncoroni, J.; Smith, R.; Verdegaal, P.; Gubler, W. Botryosphaeriaceae species spore-trapping studies in California vineyards. Plant. Dis. 2010, 94, 717-724. [CrossRef] [PubMed]

36. Amponsah, N.; Jones, E.; Ridgway, H.; Jaspers, M. Rainwater dispersal of Botryosphaeria conidia from infected grapevines. N. Z. Plant. Prot. 2009, 62, 228-233. [CrossRef]

37. Amponsah, N.T.; Jones, E.E.; Ridgway, H.J.; Jaspers, M.V. Identification, potential inoculum sources and pathogenicity of botryosphaeriaceous species associated with grapevine dieback disease in New Zealand. Eur. J. Plant. Pathol. 2011, 131, 467-482. [CrossRef]

38. Amponsah, N.T.; Jones, E.E.; Ridgway, H.J.; Jaspers, M.V. Susceptibility of grapevine tissues to Neofusicoccum luteum conidial infection. Plant. Pathol. 2012, 61, 719-729. [CrossRef] 